\title{
$S]$ IIBLION

Сосновский В.В.

\section{РЕЦЕНЗИЯ НА КНИГУ: К.Н. АВЕРИНА, Л.А. ГУРЬЕВА. ПРАВОВАЯ ОХРАНА ЛЕСОВ: СРАВНИТЕЛЬНО-ПРАВОВОЙ АНАЛИЗ}

\begin{abstract}
Аннотация: Монография посвящена чрезвычайно важной проблеме - правовой охране лесов как компонента биоразнообразия, элемента окружающей среды, одного из необходимых условий жизнедеятельности людей, источника поступлений в бюджет и сырья для промышленности. Авторы провели глубокий анализ не только законодательства и практики его реализации в России, но и в Европейском Союзе и отдельных государствахчленах ЕС, в частности во Франции и в Италии, а также в африканских странах. Особое внимание они уделили правовой охране лесов в Республике Коми, являющейся одним из наиболее богатых лесными ресурсами субъектов Российской Федерации. Такой отбор правовых систем для сравнительного анализа сейчас очень распространен в криминологии и уголовном праве: сопоставляются общие черты и особенности правового регулирования 8 странах, во многом отличающихся по уровню развития экономики, политическому устройству, традициям и культуре, но имеющие одинаковые проблемы или заинтересованные в решении этих проблем.

Review: The monograph is devoted to a highly topical problem of legal protection of forests, as a component of biological variety, an environmental element, and one of the necessary condition for human life-sustainment, income into budget, and provisions of industrial raw materials. The authors have held an in-depth analysis of legislation and lawenforcement practice in Russia, the EU, and some EU Member States, including France and Italy, as well as in some African states. Much attention is paid to the legal protection of forests in the Komi Republic, which is one of the richest constituent subjects in the Russian Federation in the forestry sphere. Such a choice of legal systems for comparative analysis is currently quite popular in forensic studies and criminal law, when the comparison of common and specific features of legal regulation in states, having different political and economical situations, but facing the same problems, or being interested in solving these problems, is held.
\end{abstract}

Ключевые слова: правовая охрана лесов, Республика Коми, правовые системы, тенденции, задачи, перспективы», новое регулирование лесопользования, административная реформа, экологическая ценность лесов, предупреждение поджогов, профилактике нарушений законодательства, лесные ресурсы

Keywords: legal protection of forests, the Komi Republic, legal systems, tendencies, goals, perspectives, new regulation of use of forests, administrative reforms, environmental value of forests, prevention of arson, prophylactics of violations of law, forest resources.

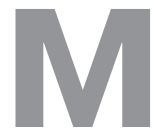
онография посвящена чрезвычайно важной проблеме - правовой охране лесов как компонента биоразнообразия, элемента окружающей среды, одного из необходимых условий жизнедеятельности людей, источника поступлений в бюджет и сырья для промышленности. Авторы провели глубокий анализ не только законодательства и практики его реализации в России, но и в Европейском
Союзе и отдельных государствах-членах ЕС, в частности во Франции и в Италии, а также в африканских странах. Особое внимание они уделили правовой охране лесов в Республике Коми, являющейся одним из наиболее богатых лесными ресурсами субъектов Российской Федерации. Такой отбор правовых систем для сравнительного анализа сейчас очень распространен в криминологии и уголовном праве: сопо- 
DOI: 10.7256/1811-9018.2013.9.9385

При цитировании этой статьи сноска на dоі обязательна

\section{Право и политика 9 (165) • 2013}

ставляются общие черты и особенности правового регулирования в странах, во многом отличающихся по уровню развития экономики, политическому устройству, традициям и культуре, но имеющие одинаковые проблемы или заинтересованные в решении этих проблем. Действительно, охрана биоразнообразия и в частности лесов перестала быть национальной проблемой - хищническая эксплуатация зеленых легких Планеты привела ко многим негативным последствиям (опустынивание, изменение климата, сокращение водных ресурсов и др.). Незаконная торговля лесными ресурсами наносит ущерб не только окружающей среде, но и экономике. Поэтому для отечественных специалистов будет, на мой взгляд, весьма полезно ознакомиться с теми задачами, которые решают сегодня в странах ЕC, и опытом (как положительным, так и отрицательным), накопленным другими государствами.

Монография состоит из предисловия научного редактора, доктора юридических наук, профессора О.Л. Дубовик, введения, трех глав, заключения и библиографии, включающей как российскую, так и иностранную литературу (с. 119-135).

Первая глава «Охрана лесов в Российской Федерации: тенденции, задачи, перспективы» включает три параграфа. Вначале рассматривается история охраны лесов в нашей стране и выявляются закономерности формирования и развития основ правового регулирования. Затем авторы анализируют предпосылки, задачи, содержание и результаты реформы лесной отрасли и лесного законодательства. Завершается глава описанием статусов субъектов правовой охраны лесов в РФ.

Обратившись к содержанию Лесного кодекса К.Н. Аверина отмечает, что определение леса не является достаточно полным и не содержит его юридических признаков (с. 28-29). «Кроме того, - пишет она, - в действующем ЛЕ РФ произошла привязка «леса» к «земле» - частичная унификация лесного и земельного законодательства. Объектом правовых отношений рассматривается земельный участок» (с. 29), но отсутствует какая-либо юридическая связь между понятиями «лес» и «земли лесного фонда», «земли иных категорий», «лесной участок». Она считает, что новое регулирование лесопользования привело к ослаблению административных и усилению договорных методов (с. 32). Отмечу, что это может привести не к повышению эффективности борьбы с коррупцией, $а$, напротив, к появлению более жестких способов оказа- ния влияния на собственников и арендаторов, вплоть до применения насилия, а также ослабить действенность профилактических мер в сфере преодоления нарушений лесного законодательства.

Авторы указывают, что Лесной кодекс РФ создал все необходимые условия в области управления лесными ресурсами для практической реализации административной реформы, начатой еще в 2004 г. (c. 36); выработаны основы возрастания роли надзорной деятельности в сфере лесных отношений (с. 37); обеспечил регулирование охраны и использования лесов на трех уровнях - федеральном, субъектов РФ и муниципальном (с. 38). Оставаясь собственником лесов, Федерация благодаря механизму передачи полномочий по управлению лесами субъектам РФ может добиться более быстрого решения многих проблем, стоящих перед отраслью лесного хозяйства и, видимо, более оперативного принятия решений и осуществления действий по охране лесов.

Вторая глава «Правовая охрана лесов в Республике Коми» состоит из трех параграфов. В них рассматриваются особенности лесного хозяйства и лесных ресурсов Республики, статус и экологическая ценность лесов на территории Печоро-Илычского заповедника и национального парка «Юлы два», деятельность субъектов правовой охраны лесов в Республике Коми и основные проблемы экологического характера, возникающие при использовании и охране лесов. Среди таких проблем выделены: незаконная рубка, лесные пожары, неразвитость системы лесных дорог (с. 50). В Республике Коми только в 2007 г. зарегистрировано 200 случаев незаконной рубки, ущерб от которой составил 22,5 млн рублей, в 2010 г. произошло 549 лесных пожаров на площади 15,5 тыс. га (с. 53), а общую обеспеченность лесного фонда дорогами можно оценить на уровне 10-12\% от требований для освоения расчетной лесосеки в полном объеме (с. 54).

Приведенные в монографии статистические данные подтверждают вывод авторов о том, что в связи со сложившейся ситуацией предупреждение поджогов в современных условиях - весьма актуальная задача. Предупреждение поджогов - это деятельность, направленная на установление лиц, замышляющих преступление, выявление фактов и обстоятельств, свидетельствующих о приготовлении к преступлению, и воздействие на лиц с целью недопущения реализации противоправного замысла. Отмечается, что «пред- 
упреждать поджоги в современных условиях сложно, поскольку они носят ситуативный характер, являясь, как правило, разрешением конфликтной ситуации и, кроме того, обычно совершаются в условиях неочевидности» (с. 55). В работах по экологическому праву, на мой, взгляд, уделяется недостаточное внимание профилактике нарушений законодательства об охране окружающей среды, поэтому рассмотрение в рецензируемой монографии данного вопроса следует приветствовать. Авторы не только ставят его, но и предлагают ряд мер, в том числе по правовой пропаганде и наглядной агитации (с. 55-56).

Третья глава «Международный и зарубежный опыт правовой охраны лесов», на мой взгляд, привлечет особое внимание специалистов. Она состоит из пяти параграфов. Первый из них посвящен основным направлениям международной политики в сфере охраны лесов, а второй - политике ЕС в этой области. В третьем и четвертом параграфах рассматриваются особенности правового регулирования и экологической политики в сфере охраны лесов во Франции и в Италии. В пятом параграфе представлены сведения о лесном хозяйстве и политике африканских стран.

В работе анализируются этапы лесной политики международного сообщества, начиная с деятельности ФАО и глобальной инвентаризации лесных ресурсов мира, Принципов лесоводства, принятых в 1992 г. в Рио-де-Жанейро, и заканчивая принятием Конвенций по охране биоразнообразия, созданием Межправительственного форума по лесам в 1997 г. и Форума ООН по лесам в 2006 г., а также проведением Министерских конференций по защите лесов Европы, осуществлением Монреальского процесса в отношении лесов бореальной и умеренной зон, деятельностью Азиатского лесного партнерства. В монографии также анализируется сотрудничество стран СНГ.

Что касается политики Европейского Союза, то в рецензируемой монографии приводятся интересные статистические данные и информация о Зеленой книге о защите лесов, опубликованной 1 марта 2010 г., о Белой книге «Адаптация к климатическим изменениям: о рамках европейской деятельности» и др. Авторы отмечают, что работа ЕС затрудняется у странучастниц Союза общего определения понятия «лес», что, правда, не мешает осуществлению принятой в ЕС Лесной стратегии, ориентирующейся на рациональное использование лесов и и их многофункциональность (c. 70). В каждой стране-участнице Евросоюза ис- пользуются разнообразные правовые инструменты: национальные лесные программы, национальная лесная инвентаризация, системы кадастровой регистрации картография отдельных регионов, их лесов и ландшафтного проектирования, обязательства по управлению лесами, схемы лицензирования. И многие другие (с.71-72).

Характеризуя лесное законодательство Италии, авторы рассматривают его эволюцию в новейший период, то есть с 1975 г., когда в целях борьбы с лесными пожарами был принят закон № 47, затем закон № 431 (1985 г.) - так называемый закон Галасса, усиливший экологическую составляющую правового регулирования охраны лесов, и другие акты.

Поскольку Франция занимает третье место в Европе по лесным площадям, в монографии анализируется лесное законодательство этой страны, начиная c 1219 г. и до наших дней, включая Лесной кодекс и изменяющие его законы. Действующий Кодекс (версия от 17 марта 2011 г.) состоит из двух частей и насчитывает более 500 статей. Авторы описывают структуру ЛК Франции (с. 86-87) и рассматривают юридические последствия принятого в нем понятия «лес». Они также характеризуют особенности управления лесным хозяйством Французской Республики, правовое положение государственных и муниципальных лесов, обязанности владельцев лесов, охрану лесов от вырубки (раскорчевывания) и пожаров, налоговые обязательства и льготы. В работе освещается история создания органов управления лесами. Так, указывается на создание Департамента здоровья лесов в 1989 г. Завершается параграф анализом направлений французской лесной политики с 2007 г., когда «стала очевидна важность профилактических и предупредительных мер по рациональному использованию и защите лесов» (с. 96). Эта политика направлена на достижение четырех задач: 1) Ценить леса как источник благосостояния государства и рабочих мест; 2) Усиливать принципы долгосрочного и рационального управления и пользования лесами; 3) Повышать ценность лесных ресурсов, лесной биомассы; 4) активно участвовать в европейских и международных действиях, касающихся лесов (с. 98-99).

Особый интерес представляет материал о лесном хозяйстве африканских стран. Л.А. Гурьева выделяет наиболее острые вопросы: обезлесение, уровень которого в два раза выше, чем в других частях Планеты; финансирование восстановления лесов, которые бо- 
DOI: 10.7256/1811-9018.2013.9.9385

При цитировании этой статьи сноска на доі обязательна

\section{Право и политика 9 (165) • 2013}

лее чем на 90\% являются государственными (в связи с этим ФАО оказывает значительную поддержку, например. в 2010-2011 гг. обеспечив финансирование лесных проектов на сумму 42 млн. долларов США). В параграфе рассматривается содержание различных программ по восстановлению и сохранению лесов Африки, в том числе реализуемого с 2012 г. проекта по установлению современных национальных систем контроля над лесами в бассейне реки Конго, и деятельность Африканской комиссии по лесному хозяйству и дикой природе, которая разработала рекомендации, касающиеся усиления участия местных органов власти в управлении охраняемыми лесами, справедливом распределении получаемых выгод, отбора наиболее важной недревесной лесной продукции с учетом потребностей местного населения и условий рынка, развития и использования альтернативных источников энергии, переработки национальных лесных программ и др. (с. 104-105). Приводятся данные об охране лесов в Камеруне, Гамбии, Республике Конго и других странах.

Оценивая рецензируемую работу, в первую очередь, следует отметить ценность представленной в ней правовой, статистической и экологической информации. Причем информации не только о зару- бежном праве и политике, но и о праве российском и о том, каким образом реализуются требования закона об охране лесов в нашей стране. Относительно небольшой объем монографии, видимо, не позволил авторам более подробно проанализировать меры контрольно-надзорного характера и специфику юридической ответственности за нарушение лесного законодательства в странах ЕС. Можно пожелать К.Н. Авериной и Л.А. Гурьевой продолжить столь успешно и ярко начатые исследования проблематики охраны лесов в России и за рубежом.

\section{Библиография:}

1. Лесной кодекс РФ 2004 г.;

2. Принципов лесоводства, 1992 г. Рио-де-Жанейро;

3. Конвенция по охране биоразнообразия, (Материалы Межправительственного форума по лесам в 1997 г. и Форума ООН по лесам в 2006 г.);

4. Зеленая книга о защите лесов,2010 г.;

5. Закон Италии "О лесном законодательстве" № 47,1975 г.;

6. Закон Италии № 431, 1985 г. - (закон Галасса);

7. Лесной кодекс Франции от 17 марта 2011 г.; 